\title{
Social acceptance levels of normal developed students towards disable students
}

\author{
Buse Özlü ${ }^{1}$, Nergüz Bulut Serin ${ }^{2}$ \\ ${ }^{1}$ Ministry of National Education, Burdur, Turkey \\ ${ }^{2}$ Department of Guidance and Psychological Counseling, Faculty of Education, European University of Lefke, Turkey
}

\begin{abstract}
Article Info
Article history:

Received Mar 10, 2021

Revised Aug 24, 2021

Accepted Sep 8, 2021

Keywords:

Disabled individual

Secondary school students

Self-esteem

Social acceptance

ABSTRACT

The study aimed to examine whether there is a significant difference between the social acceptance levels of the students with disabilities in the middle school students with normal development according to the variables of gender, grade level, number of siblings, and income level. This study was carried out in general screening model with appropriate sampling model. The universe of this research consists of 6th and 7th grade students. The sample of the study consists of 220 students. Social acceptance scale was used to collect data. One-way analysis of variance (t-test) were calculated using test techniques. As a result of the research, it was observed that the average score of peer attitude of female students was higher than male students. No significant difference was found between the social acceptance scale subscales, social skills, and student behavior subscales and social acceptance scale total scores of students with normal development according to their grade level. According to the number of participants' siblings, a significant difference was found between the student behavior subscale of the social acceptance scale and the total score averages of the social acceptance scale.
\end{abstract}

This is an open access article under the $\underline{C C B Y-S A}$ license.

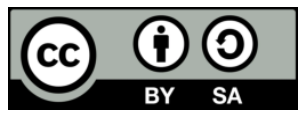

\section{Corresponding Author:}

Nergüz Bulut Serin

Department of Guidance and Psychological Counseling, Faculty of Education

European University of Lefke

Lefke, Northern Cyprus TR-10 Mersin, Turkey

Email: nserin@eul.edu.tr

\section{INTRODUCTION}

Different special education services are provided according to the development and learning characteristics of individuals with disability to continue their lives independently in the society. It covers different educational services, the students with disability studying with their peers through normal growth to living by care in residential institutions [1]. It is defined as social acceptance that normally developing students have positive attitudes towards students with special needs and accept them as one of them [2].

The purpose of integration practices is not only to increase the academic skills of the students with disable students, but also to increase their social skills and social acceptance, as well as to improve their empathic skills and positive self-esteem [3]. There are studies on the effect of inclusive educational practices on the social acceptance of students with special needs. Determining the social acceptance levels of students with disable students who participate in mainstreaming applications when researches on the subject are examined [4], [5]. It is seen that researches have been conducted to inform normally growing individuals about disable students and the relationship between this situation and the social acceptance levels of these students [6]-[8]. The exceptionally gifted students have frequently verbal arguments and this arises mainly from their competitive personalities. The students specifies that the controversies they have may be solved 
with the face to face communication and this situation has no influence either on their courses or friendship [8], [9]. It is recommended that all primary teachers consider the best practice of social support within their own classroom, and further research be carried out to investigate best practice in fostering and supporting the social growth and needs of students with autism spectrum disorder (ASD) [10]. According to Kahveci [11], the proactive model emphasizes the conceptual, operational, evaluative, public relations, and personal development of student counsellors. These components are sequenced, interrelated, and precede one another in significance during implementation.

Social acceptance is defined as the acceptance of individuals to their groups and relationships by others, being chosen as a group member for assembly activities, and being adopted by their friends [6], [12]. Cagran and Schmidt [13] show that a successful implementation of inclusion of children with special needs (SN) largely depends on the teachers' positive attitude towards it. In other words, it is expressed as social acceptance that students have positive attitudes towards disable students, see them as they are and accept their participation in their activities [2]. Having social abilities does not mean that the individual will be on a social basis competent and accepted by the society [14]. Social acceptance is also an important factor for the socialization of students with disabilities. On the contrary, not being accepted by their peers decreases the sense of self-confidence and causes anxious and timid behaviors to increase [3]. Negative attitudes of the peers, teachers and other people actively involved in the implementation process of inclusive education of disable students may cause these individuals to experience loneliness and social exclusion [15], [16].

As a result of negative attitudes, teachers' not taking into account the needs of students with disable and not meeting these disabilities, focusing more on students with normal development can be considered as the most important factors that prevent the realization of social acceptance [17]. Students with disabilities may also show delays in social skills, which also affect academic achievement, compared to their peers, and these inadequacies can lead to a decrease in the level of social acceptance in the classroom with the addition of problematic behaviors [18]. Teachers' positive attitudes towards students with disabilities, providing them with peer support, and making environments that enable them to learn by having fun in the classroom are very important in increasing the social acceptance of those students [19], [20]. According to Kahveci and Serin [21], children with learning disabilities are at greater risk of being victims of sexual abuse in schools.

It is stated that appreciations to the education of students with special needs in the same environment with their coevals, their social skills develop and they develop in social, emotional and academic fields through the interaction they establish [22]. Families who share responsibilities related to their children are respected as important partners by experts, activities for the student are carried out jointly in a coordinated method, accordingly simplifying the process of gaining skills functionally [23]. Saltalı and İmir [24] examines children's aggressive, prosocial and socially inhibited behaviors in association with parenting dimensions namely warmth, inductive-reasoning, obedience-demanding and punitive. Based on Kahveci and Selcuk [25], parent training programs have proven the most effective way to treat child behavior problems. Without effective treatment, disruptive or problem behavior problems related long-term outcomes include academic difficulties in late school years unemployment, family problems, and mental health problems such as depression, anxiety disorders, addiction, and antisocial personality disorders. The relations of students in the educational environment with their teachers and the quality of these relationships; they play an important role in the emotional, social and academic development of students [26], [27]. However, when it comes to mainstreaming education practice, it has been revealed through research that teachers do not consider themselves competent [28]-[33].

Peers play an important role in the psychosocial development of most of their coevals. The support of peers is providing opportunities for individuals to gain interpersonal relationships, social skills and a sense of involvement. In order to achieve the success in combining; It is seen in researches that informing normal peers, families, teachers, school administration and other staff about students with normal special development, organizing coalescence activities plays an important role in the social acceptance of those students [3], [6], [8], [18], [34]. It is one of the most important indicators of contemporary education that inclusive students receive education in the same environment with normal students without making any difference. It is important for teachers and parents to support these differences by evaluating them positively in educational settings. In this situation, it has revealed that more studies should be carried out to determine the social acceptance levels of students with normal developing towards students with disabilities.

The aim of this study is to examine whether there is a significant difference in the social acceptance levels of disable students towards disable students in secondary schools in the city center of Burdur, Turkey according to the variables of gender, grade level, number of siblings, incoming level, and whether there are individuals with disabilities in the family. For this purpose, the following questions were required: i) Is there a significant difference in the social acceptance levels of secondary school students towards disable students according to the variables of gender, grade level, number of siblings, income level?; and ii) Are there individuals with special needs disabilities in the family? 


\section{RESEARCH METHOD}

In this study, the descriptive screening model was used as it was aimed whether there was a significant difference in the social acceptance levels of the disable students towards the students with disabilities in secondary schools in the city center of Burdur according to the variables of gender, grade level, number of siblings, income level and whether there are individuals with disabilities in families. This model is a method of empirical analysis used to evaluate the interactions between more than one component. Examines the interaction between variables.

\subsection{Population and sample}

The population of this study consists of three secondary schools in the city center of Burdur, Turkey between 2019-2020, which affiliated to the Ministry of National Education. The sample of the study consists of a total 220 students, $130(59.1 \%)$ female and $90(40.9 \%)$ male, studying in three secondary schools in the province of Burdur. There were 110 of students who are on the 6th grade and 110 of them are 7 th grade students. The sample of the study consists of the students who can meet from the students studying in three secondary schools. The required sampling procedure, one of the non-random sampling techniques, was used to determine the test sample. There were 220 students included in the study. After the approval of the Ethics Committee for this study, written consent was obtained from the appropriate institutions before the study.

\subsection{Data collection tools}

Social acceptance scale developed by Arslan [5] is a Likert-type scale with a triple rating of 32 points. As a result of the exploratory factor analysis for the construct validity of the scale, a three-factor structure was determined. The percentage of explaining the total variance of the three-factor structure is $46.66 \%$. The three factors that make up the scale is defined as social skills, student behavior, and peer attitude. In the reliability analysis of the scale, the Cronbach Alpha Internal Consistency Coefficient was found as .92. The high value taken from the scale indicates that the students have developed a positive attitude towards the mainstreaming students, while the low value indicate that the students have developed a negative attitude. In this study, the Cronbach's Alpha value of the scale was found .93.

\subsection{Data analysis}

The arithmetic means, standard deviations, t-test, using one-way analysis of variance (ANOVA) analysis of the data in the applied scale will be calculated using the SPSS 20 package program on the computer. The level of importance in the study was accepted as .05.

\section{RESULTS}

The findings obtained for the sub-problems determined in line with the purpose of this research are presented in the following order. Table 1 examines no significant difference was found between the total score averages of the social acceptance scale subscales, social skills, student behavior subscales, and social acceptance scale of the participants with normal development by gender. However, a significant difference was found according to the peer attitude subscale of the social acceptance scale. Accordingly, it was observed that female students' peer attitude towards students with special needs was higher than male students.

Table 2 shows a significant difference was found according to the peer attitude subscale of the social acceptance scale subscales of the 6th grade and 7th grade participants with normal development. Accordingly, 6th grade students' average of peer attitude towards disable students is higher than 7 th grade students. Table 3 presents a significant difference was found between the total score averages of the social acceptance scale sub-scales student behavior subscale and social acceptance scale according to the income level of the students with normal development. Middle-income students have higher social acceptance levels for students with disabilities than high-income students.

Table 1. Analysis of the social acceptance scale and social acceptance subscales score average of the participants by gender

\begin{tabular}{|c|c|c|c|c|c|}
\hline \multirow{3}{*}{ Dependent variables } & \multicolumn{4}{|c|}{ Gender } & \multirow{3}{*}{$\begin{array}{c}\text { P-Value } \\
\text { (Sig.) }\end{array}$} \\
\hline & \multicolumn{2}{|c|}{ Male } & \multicolumn{2}{|c|}{ Female } & \\
\hline & Mean & Std. Dev & Mean & Std. Dev. & \\
\hline Social acceptance & 37.911 & 7.810 & 39.261 & 7.391 & .201 \\
\hline Student behavior & 25.188 & 2.647 & 25.600 & 2.604 & .287 \\
\hline Peer attitude & 18.388 & 2.629 & 19.238 & 2.018 & $.011 *$ \\
\hline Social acceptance scale & 81.488 & 11.594 & 84.100 & 10.867 & .096 \\
\hline
\end{tabular}


Table 2. Social acceptance scale and social acceptance sub-scale score averages analysis by class level of participants

\begin{tabular}{cccccc}
\hline \multirow{2}{*}{ Dependent variables } & \multicolumn{4}{c}{ Class level } & \multirow{2}{*}{ P-Value } \\
& Mean & Std. Dev & Mean & Std. Dev. & (Sig.) \\
\hline Social acceptance & 39.236 & 7.343 & 38.181 & 7.801 & .356 \\
Student behavior & 25.336 & 2.845 & 25.527 & 2.391 & .686 \\
Peer attitude & 19.245 & 2.151 & 18.536 & 2.437 & $.008^{*}$ \\
Social acceptance scale & 83.818 & 11.265 & 82.245 & 11.167 & .225 \\
\hline$* \mathrm{p}<.05$ & & & &
\end{tabular}

Table 3. Social acceptance scale and social acceptance subscales score average analysis according to the income level of the participants' family

\begin{tabular}{cccccccc}
\hline & \multicolumn{9}{c}{ Level of the participants' family } \\
Dependent variables & \multicolumn{2}{c}{$0-3,000 \mathrm{TL}$} & \multicolumn{2}{c}{$3,000 \mathrm{TL}-4,000 \mathrm{TL}$} & 4,000 TL and above & P-Value (Sig.) \\
& Mean & Std. Dev & Mean & Std. Dev & Average & Std. Dev & \\
\hline Social acceptance & 40.181 & 5.095 & 40.049 & 6.912 & 37.674 & 8.275 & .169 \\
Student behavior & 25.818 & 1.424 & 25.901 & 1.903 & 25.103 & 3.090 & $.038^{*}$ \\
Peer attitude & 18.697 & 2.567 & 19.163 & 1.881 & 18.809 & 2.448 & .652 \\
Social acceptance scale & 84.697 & 7.359 & 85.114 & 9.681 & 81.587 & 12.517 & $.029^{*}$ \\
\hline * $<$ <.05 & \multicolumn{10}{c}{}
\end{tabular}
*p<.05

Table 4 shows that a significant difference was not found between the social acceptance scale and subscales mean scores of the participants with normal development according to whether there is a family member with special needs or not. Table 5 examines that a significant difference was found between the total score averages of the social acceptance scale subscales, student behavior subscale, and social acceptance scale, according to the number of siblings of the participants with normal development. Accordingly, students with three or more siblings have a higher level of positive social acceptance than students with one sibling. However, no significant difference was found according to the peer attitude and social skills subscale, which are the subscales of the social acceptance scale.

Table 4. Social acceptance scale and subscale analysis according to whether there is a family member with

\begin{tabular}{cccccc}
\multicolumn{7}{c}{ special needs or not } \\
\hline \multirow{2}{*}{ Dependent variables } & \multicolumn{2}{c}{ Yes member with special needs or not } & \multirow{2}{*}{ P-Value } \\
& Mean & Std. Dev & Mean & Std. Dev & (Sig.) \\
\hline Social acceptance & 41.000 & 6.144 & 38.611 & 7.628 & .380 \\
Student behavior & 26.111 & 1.833 & 25.402 & 2.651 & .186 \\
Peer attitude & 19.666 & 1.322 & 18.857 & 2.350 & .408 \\
Social acceptance scale & 86.777 & 8.212 & 82.872 & 11.316 & .323 \\
\hline $\mathrm{p}<.05$ & & & & &
\end{tabular}

Table 5. Social acceptance scale and social acceptance subscales score average analysis according to the number of siblings of the respondents

\begin{tabular}{cccccccc}
\hline \multirow{2}{*}{ Dependent variables } & \multicolumn{2}{c}{ Number of siblings } & \multicolumn{2}{c}{3 and above } & P-Value \\
& Mean & Std. Dev & Mean & Std. Dev & Mean & Std. Dev & (Sig.) \\
\hline Social acceptance & 37.301 & 8.406 & 38.989 & 7.242 & 39.733 & 7.085 & .268 \\
Student behavior & 24.650 & 3.460 & 25.721 & 2.308 & 25.783 & 1.841 & $.042^{*}$ \\
$\quad$ Peer attitude & 18.365 & 2.665 & 19.195 & 2.148 & 18.950 & 2.134 & .089 \\
Social acceptance scale & 80.317 & 12.868 & 83.907 & 10.458 & 84.466 & 10.195 & $.045^{*}$ \\
\hline * $<$ <.05 & & & & & & &
\end{tabular}

\section{DISCUSSION}

In general, when the results of the study were evaluated, it was seen that the average score of peer attitude of female students was higher than male students. In this context, female students with normal development have found a higher level of positive peer attitudes towards disable students than male students. This situation can be explained by the fact that females' social skills and communication skills are at a higher level than male students and that females are better than males in disclosing and expressing themselves. In general, social acceptance, no significant difference was found in terms of gender. Previous studies [4], [35] 
found a significant difference between social acceptance level and gender in their study. Ayral, et al. [36] found that there is no significant difference between social acceptance and gender in their study, where they examined social acceptance levels of inclusive students. These research findings support the findings of the present study.

No significant difference was found between the total scores of the social acceptance scale subscales, social skills, and student behavior subscales and social acceptance scale according to the grade level of students with normal development. However, a significant difference was found according to the peer attitude subscale of the social acceptance scale. Accordingly, 6th grade students' average of peer attitude towards disable students is higher than 7th grade students. Concordantly, it can be said that as the grade level increases, the positive peer attitudes of students towards students with disability decrease. Civelek [6] found in his study that students with low social acceptance level were not accepted by their peers, causing them to feel inadequate, behave more negatively and avoid social relationships. Sucuoglu and Ozokcu [37] found that the social skills and academic competence of normally developing students were less than their peers, and their problematic behaviors were higher than their peers. Petry [38] found that normal students generally have neutral attitudes towards their disabled peers at grade level, but social acceptance level varies according to disability status. According to Gurkan [39], peers who are educated together with disabled children can become aware of personal differences and develop a positive attitude towards these differences. Based on Kahveci and Serin [21], results show immediate improvements in disruptive and aggressive behavior. Additionally, follow up observations revealed maintenance of intervention effects. Although use of a multiple baseline design had restricted use in experimental control, preliminary results indicate that the Individualized Social Skills Program may be useful for eliminating disruptive and aggressive behaviors.

According to the number of siblings of the respondents, a significant difference was found between the student behavior subscale of the social acceptance scale and the total score averages of the social acceptance scale. Students with three or more siblings have a higher level of positive social acceptance than students with only one sibling. This situation can be explained as having more than one sibling creates a positive environment for students to increase their communication and social skills and these students increase their social acceptance towards disable students. Gulay [40] revealed that the social skills that children learn as a result of sibling relationships vary according to the number of siblings. Sarı [41] found that social adaptation and social skills of children with their peers differ significantly according to the number of siblings. The present study supports the findings.

Previous studies [35], [36] concluded that there was no relationship between the number of siblings and the social acceptance level of the mainstreaming student. No significant difference was found between the social acceptance scale and its subscales mean scores according to whether there is a family member with disability or not. Ayral, et al. [36] stated that students' having a disabled sibling did not affect their level of social acceptance. This finding supports the current research. Aktan, Budak, and Botabekovna [4] in their study confirmed that there was no significant difference between the social acceptance levels of individuals with disables according to whether there is a person with disables in their family and close society. Kahveci and Selcuk [25] stated that the Parent Child Interaction Therapy (PCIT) is effective in reducing destructive behavior problems, supporting parental interactions in a positive way, supporting the positive change of the home atmosphere and family wellbeing, and establishing an independent individual by making a healthy separation of the respondent from the mother possible.

A significant difference was found between the total score averages of the social acceptance scale subscales, student behaviors subscale and social acceptance scale according to the income level of students with normal development. Middle-income students have higher social acceptance levels for disable students with special needs than high-income students. In the literature, there are studies showing that students' social acceptance does not differ significantly according to family income [4], [36], [42], studies differ from the present study findings. Boutot [43] defined social acceptance as individuals who are not affected by disability having positive attitudes towards individuals affected by disability and seeing them as others. Ogelman, Göktaş, and Aytaç [44] young children according to the It attaches importance to social skills, mutual sharing, spending time outside the game, and relationships based on kindness and love. They do not like rude, bullying, and disorganized behavior in their peer relationships. According to Suyatno [45], the improvement of the ability of the students' social adjustment should become a priority for educational institutions since it constitutes the predictor of someone's success.

\section{CONCLUSION}

In general, when the results of the study are evaluated, female students with normal development have higher level of positive peer attitudes as disable students than male students. Considering the findings of this research, it is important that the psychological counsellors working in the school guidance services to 
organize psycho-education programs or informative seminars and conferences for increasing the positive attitudes of male students towards disable students. In terms of the number of siblings' variable, students with three or more siblings have a higher level of positive social acceptance than students with one sibling. Considering that the result of this research increases social skills, it is important in terms of emphasizing the importance of the trainings to be made to develop social skills for other siblings in the family.

This research has some limitations. In this study, social acceptance levels of only middle school 6th and 7th grade students towards disable students were investigated. The limitation of this study in terms of methods is that it is a descriptive study and is insufficient to explain causal relationships. Another limitation of this study that was implemented in three secondary schools in only one city center and it did not consider the socio-economic levels of the respondents. In future studies, it may be more appropriate to conduct quantitative and qualitative studies with larger and heterogeneous working groups. These are serious restriction and limitations of the study. However, researches on this subject are more recent and appear to be limited. It is thought that the results of this study will contribute significantly to the development of positive social acceptance and positive attitudes towards individuals with special needs. In new studies to be carried out about this subject could be suggested to work with students from different education levels, with different variables, and students from different age groups. It is thought that students with normal development will contribute to new studies that will investigate the positive social acceptance levels of disable students and will guide similar studies.

\section{ACKNOWLEDGEMENTS}

This article is based on a master's thesis conducted under the direction of the second author by the first author in the area of Guidance and Psychological Counselling at the European University of Lefke Institute of Graduate Studies and Research.

\section{REFERENCES}

[1] A. Sığırtmaç and E. Gül, Okul öncesinde özel eğitim. Ankara: Kök Publishing, 2008.

[2] M. Özyürek, Engellilere Yönelik Tutumların Değiştirilmesi. Ankara: Kök Publishing, 2006.

[3] C. Aktaş, and S. Küçüker, "Bilişsel-duyuşsal odaklı bir programın ilköğretim öğrencilerinin fiziksel engelli yaşıtlarına yönelik sosyal kabul düzeylerine etkisinin incelenmesi," Ankara University Faculty of Educational Sciences Journal of Special Education, vol. 3, no. 2, pp. 15-25, 2002.

[4] O. Aktan, Y. Budak, and A. B. Botabekovna, "Determination of social acceptance levels of primary school students towards inclusive students: A mixed method study," Element. Educ. Online, vol. 18, no. 4, pp. 1520-1538, 2019.

[5] E. Arslan, "A scale development study of social acceptance levels for disabled students who integrated primary school," Unpublished Master's Thesis, Mehmet Akif Ersoy University, Burdur, 2010.

[6] A. H. Civelek, "Eğitilebilir zihinsel özürlü çocukların sosyal kabul görmelerinde normal çocukların bilgilendirilmelerinin ve iki grubun resim-iş ile beden eğitimi derslerinde bütünleştirilmelerinin etkileri," Unpublished Doctoral Dissertation, Ankara University, Ankara, 1990.

[7] Ö. Özkan-Yaşaran, S. Batu and A. Özen, "The effects of inclusion preparation activities on providing social acceptance of typical students for students with special needs," Anadolu University Journal of Social Sciences (AUJSS), vol. 14, no. 3, pp. 167-180, 2014, doi: 10.18037/ausbd.92732.

[8] Ü. Şahbaz, "The influence of informing normal students attending integrated classes on retarded students' social acceptance levels," Eurasian Journal of Educational Research, no. 26, pp. 199-208, 2007. [Online]. Available: https://app.trdizin.gov.tr/publication/paper/detail/TmprMU1ESXk.

[9] O. Serin, N. B. Serin, and G. Sayg1l1, "The conflicts that exceptionally gifted students encounter and their opinions, observations and experiences regarding the solutions of these conflicts," The Anthropologist, vol. 23, no. 1-2, pp. 185-193, 2016.

[10] J. Gledhill and J. Currie, "Characteristics of teachers' recommended social support strategies for primary students with ASD,” International Online Journal of Primary Education (IOJPE), vol. 9, no. 1, pp. 18-34, 2020.

[11] G. Kahveci, "School counseling and students with disabilities," International Online Journal of Primary Education, vol. 5, no. 2, pp. 15-22, 2016.

[12] E. A. Nowicki, "A Meta-analysis of the social competence of children with learning disabilities compared to classmates of low and average to high achievement," Learning Disability Quarterly, vol. 26, no. 3, pp. 171-188, 2003, doi: 10.2307/1593650.

[13] B. Cagran and M. Schmidt, "Attitudes of Slovene teachers towards the inclusion of pupils with different types of special needs in primary school," Educational Studies, vol. 37, no. 2, pp. 171-195, 2011, doi: 10.1080/03055698.2010.506319.

[14] İ. Çifci and B. Sucuoğlu, Bilişsel süreç yaklaşımıyla sosyal beceri öğretimi. Ankara: Kök Publishing, 2012.

[15] A. Boer, S. J. Pijl, and A. Minnaert, "Students' attitudes towards peers with disabilities: a review of the literature," International Journal of Disability, Development and Education, vol. 59, no. 4, pp. 379-392, 2012, doi: 10.1080/1034912X.2012.723944. 
[16] S. Verte, H. Roeyers and A. Buysse, "Behavioural problems, social competence and self-concept in siblings of children with autism," Child Care Health Dev., vol. 29, no. 3, pp. 193-205, 2003.

[17] A. Garrote, "Relationship between social participation and social skills of pupils with an intellectual disability: A study in inclusive classrooms," Frontline Learning Research, vol. 5, no. 1, pp. 1-15, 2017. doi: 10.14786/flr.v5i1.266.

[18] B. Sucuoğlu and T. Kargın, İlköğretimde kaynaştırma uygulamaları. Ankara: Kök Publishing, 2014.

[19] S. Sidekli, "Sınıf akranlarıyla kaynaştırmayı destekleme," M. Şahin and T. Altun, Ed., Kaynaştırma sınıfi: Etkili farklılaştırılmış ögretim için stratejiler. Ankara: Nobel Publishing, 2016.

[20] H. Avcioğlu, "Classroom teachers' behaviors and peers' acceptance of students in inclusive classrooms," Educational Sciences: Theory \& Practice, vol. 17, no. 2, pp. 463-492, 2017.

[21] G. Kahveci and N. B. Serin, "Individualized social skills program for decreasing disruptive and aggressive behaviors in high-incidence disabilities," Electronic Turkish Studies, vol. 12, no. 18, pp. 395-408, 2017, doi: 10.7827/TurkishStudies.12083.

[22] A. Sı̆̆ırtmaç and E. Gül, Erken çocuklukta özel eğitim ve kaynaştırma. Ankara: Vize Publishing, 2018.

[23] H. Bayraklı and B. Sucuoğlu, Okul öncesinde kaynaştırma eğitimi. Ankara: Pegem Akademy, 2017.

[24] N. D. Saltal1 and H. M. İmir, "Parenting styles as a predictor of the preschool children's social behaviours," Participatory Educational Research, vol. 5, no. 2, pp. 18-37, 2018.

[25] G. Kahveci and M. Selçuk, "Aile-çocuk etkileşim terapisinin (AÇET) dikkat eksikliği hiperaktivite bozukluğuna sahip bir çocuk üzerindeki etkileri," Turkish International Journal of Special Education and Guidance \& Counselling (TIJSEG), vol. 7, no. 1, pp. 28-40, 2018

[26] K. F. McGrath and P. V. Bergen, "Who, when, why and to what end? Students at risk of negative student-teacher relationships and their outcomes," Educational Research Review, vol. 14, pp. 1-17, Feb. 2015, doi: 10.1016/j.edurev.2014.12.001.

[27] F. Yener, "Sorunlu öğrenci davranışlarının çözümünde yönetici ve öğretmenlerin rol model davranışlarının önemi," Unpublished Master's Thesis, Kocaeli University, Kocaeli, 2011.

[28] G. Akçamete, Özel gereksinimli ögrrenciler için kaynaştırma modeli geliştirme projesi. Ankara: Ankara Üniversitesi Bilimsel Araştırma Projeleri, 2009

[29] E. Allen and G. E. Cowdery, The exceptional child: Inclusion in early childhood education. Belmont, CA: Wadsworth/Cengage Learning, 2012.

[30] E. S. Batu, "Kaynaştırma, destek hizmetler ve kaynaştırmaya hazırlık etkinlikleri," Ankara University Faculty of Educational Sciences Journal of Special Education, vol. 2, no. 4, pp. 35-45, 2000.

[31] E. S. Batu and G. Kurcaali-İftar, Kaynaştırma. Ankara: Kök Publishing, 2011.

[32] H. Gürgür, D. Büyükköse and Ç. Kol, "Özel eğitim ve rehabilitasyon merkezlerinde işitme kayıplı öğrencilere sunulan destek hizmetler: Öğretmen görüşleri,” Elementary Education Online, vol. 15, no. 4, pp. 1234-1253, 2016, doi: $10.17051 /$ io.2016.32423.

[33] A. Sığırtmaç and H. Çulhaoğlu İmrak, "Kaynaştırma uygulanan okulöncesi sınıflarında akran ilișkilerinin incelenmesi," International Journal of Early Childhood Special Education, vol. 3, no. 1, pp. 38-65, 2011.

[34] B. Sucuoğlu and H. Bakkaloğlu, Okul öncesinde kaynaștırma: Öğretmen eğitimi. Ankara: Pegem Akademy, 2016.

[35] Z. Karataş and E. Arslan, "Ortaokulda öğrenim gören zihin engelli kaynaştırma öğrencilerinin normal gelişim gösteren akranları tarafindan sosyal kabullerinin incelenmesi," Mehmet Akif Ersoy University Journal of Education Faculty, vol. 1, no. 48, pp. 495-513, 2018

[36] M. Ayral, et al., "Kaynaştırma öğrencilerinin sosyal kabul düzeyleri," ELMIS Uluslararası Özel Eğitim Kongresi, Akşehir, 2013.

[37] B. Sucuoğlu and O. Özokçu, "Kaynaştırma öğrencilerinin sosyal becerilerinin değerlendirilmesi," Ankara University Faculty of Educational Sciences Journal of Special Education, vol. 6, no. 1, pp. 41-57, 2005.

[38] K. Petry, "The relationship between class attitudes towards peers with a disability and peer acceptance, friendships and peer interactions of students with a disability in regular secondary schools," European Journal of Special Needs Education, vol. 33, no. 2, pp. 254-268, 2018.

[39] M. Gürkan, Okullarımızda neden niçin nasıl kaynaştırma: Yönetici, öğretmen ve aile kılavuzu. Ankara: MEB Özel Eğitim Rehberlik ve Danışma Hizmetleri Genel Müdürlüğü, 2010.

[40] H. Gülay, "5-6 Yaş çocuklarına yönelik akran ilişkileri ölçeklerinin geçerlik güvenirlik çalışmaları ve akran ilişkilerinin çeşitli değişkenler açısından incelenmesi," Unpublished Doctoral Dissertation, Marmara University, İstanbul, 2008.

[41] E. Sarı, "Anasınıfına devam eden 5-6 yaş grubu çocukların, annelerinin çocuk yetiştirme tutumlarının, çocuğun sosyal uyum ve becerilerine etkisinin incelenmesi," Unpublished Master's Thesis, Gazi University, Ankara, 2007.

[42] C. Aydoğan, "Farklı yaşam dönemlerindeki bireylerin zihinsel engelli bireylere ilişkin sosyal kabulleri," Unpublished Master's Thesis, Y1ldırım Beyazit University, Ankara, 2017.

[43] E.A. Boutot, "Fitting in: Tips for promoting acceptance and friendships for students with autism spectrum disorders in inclusive classrooms," Intervention in School and Clinic, vol. 42, no. 3, pp. 156-161, 2007, doi: $10.1177 / 10534512070420030401$.

[44] H. G. Ogelman, İ. Göktaş, and P. Aytaç, "The reasons for young children to like and dislike playing with their friends," International Online Journal of Primary Education (IOJPE), vol. 9, no. 2, pp. 2316-326, 2020.

[45] K. N. H. Suyatno, "Emotional intelligence affect social adjustment ability among primary school students," International Journal of Evaluation and Research in Education (IJERE), vol. 7, no. 4, pp. 270-278, 2018. 